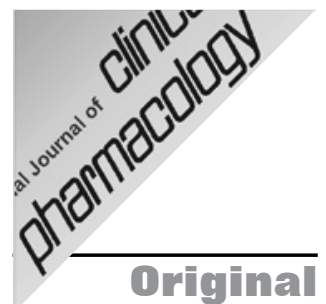

๑2014 Dustri-Verlag Dr. K. Feistle ISSN 0946-1965

DOI 10.5414/CP201972 e-pub: February 19, 2014

\section{Key words}

glomerulonephritis

- drug metabolizing

enzymes - transporters - uridine glucuronosyltransferases (UGTs) cytochrome P450 2B9 - $\mathrm{ABCB} 1$ - $\mathrm{ABCC} 2$ $A B C G 2$
Received

May 21, 2013;

accepted

July 21, 2013

Correspondence to Melanie S. Joy, PharmD, PhD, FCCP, FASN University of Colorado Anschutz Medical Campus, Skaggs School of Pharmacy and Pharmaceutical Sciences, Mail Stop C238, Room V20-4108, 12850 E. Montview Blvd, Aurora, CO 80045, USA Melanie.Joy@ ucdenver.edu

\title{
A pilot study of leukocyte expression patterns for drug metabolizing enzyme and transporter transcripts in autoimmune glomerulonephritis
}

\author{
Melanie S. Joy ${ }^{1,2}$, Brittney V. Roberts ${ }^{1}$, Jinzhao Wang ${ }^{2}$, Yichun $\mathrm{Hu}^{2}$, \\ Susan L. Hogan' ${ }^{2}$, and Ronald J. Falk ${ }^{2}$ \\ ${ }^{1}$ University of Colorado, Skaggs School of Pharmacy and Pharmaceutical Sciences, \\ Aurora, CO and ${ }^{2}$ University of North Carolina, Division of Nephrology and \\ Hypertension, UNC Kidney Center, Chapel Hill, NC, USA
}

\begin{abstract}
Objective: Leukocyte mRNA expression patterns of drug metabolizing enzyme genes and transporter genes that are relevant for the disposition of cyclophosphamide and mycophenolate were studied. The relationships between expression and patient-level data and pharmacokinetics were evaluated. Methods: The study included

metabolizing enzyme and transporter transcripts and contributes to the literature on transcript expression of drug transporters in leukocytes. The implications of altered local metabolism and transport in leukocytes may be important in autoimmune diseases and transplant patients where treatment is targeted to leukocytes.
\end{abstract} patients with glomerulonephritis secondary to lupus nephritis (SLE, $\mathrm{n}=36$ ), small vessel vasculitis $(\mathrm{SVV}, \mathrm{n}=35)$, healthy controls $(\mathrm{HC}, \mathrm{n}=10)$, and disease controls (VC, $\mathrm{n}=5 ; \mathrm{LC}, \mathrm{n}=5$ ). Transcript assays targeted metabolizing enzymes (UGT1A7, UGT1A9, UGT2B7, CYP $3 A 4$, CYP2C9, $C Y P 2 B 6)$ and transporters $(A B C B 1, A B C C 2$, $A B C G 2, S L C O 1 A 2)$. Genotyping for specific variants was conducted. Group transcript fold-changes were evaluated. Patient level data was evaluated for transcript foldchange and disease, treatment, gender, race, and genotype. Results: Significant differences were noted in expression of UGT1A7, $A B C B 1$, and $A B C C 2$; for $U G T 1 A 7, \mathrm{SVV}$ $(0.17 \pm 0.42 ; \mathrm{p}<0.05)$ and $\operatorname{SLE}(0.03 \pm 0.1$; $\mathrm{p}<0.05)$ groups had lower expression than $\mathrm{HC}(0.79 \pm 2.02)$. For $A B C B 1$, SLE had a lower expression $(0.33 \pm 0.21 ; \mathrm{p}<0.05)$ than HCs $(1 \pm 0.82)$. For $A B C G 2$, SVV group had a lower expression $(0.17 \pm 0.14$; $\mathrm{p}<0.05)$ than HCs $(1 \pm 1.82)$. Differences in expression of $A B C C 2$ approached statistical significance with $\mathrm{VC}$ patients $(2.02 \pm 1.13)$ exhibiting higher expression than SVV patients $(1.06 \pm 1.11 ; p=0.05)$. The relationships between transcript expression and patient-level data demonstrated; $A B C C 2$ expression was different by race $(1.26 \pm 1.82$ Caucasian versus $1.37 \pm 0.86$ non-Caucasian; $\mathrm{p}=0.049)$ and $C Y P 2 B 6$ expression was different by treatment $(2.07 \pm 2.94 \mathrm{cy}$ clophosphamide versus $0.45 \pm 0.5$ mycophenolate; $\mathrm{p}=0.01)$. Conclusions: The current study showed differential expression of drug

\section{Introduction}

The mRNA expression patterns of drug metabolizing enzymes and transporters in peripheral blood cells (neutrophils, lymphocytes, and monocytes) are thought to be important in patient responses to treatments for glomerulonephritis since the localized target of the pharmacological agents (e.g., mycophenolate and cyclophosphamide) are the leukocytes. The active therapeutic component of mycophenolate (mycophenolic acid) is transformed to inactive glucuronide metabolites after exposure to uridine diphosphate glucuronosyltransferases (UGTs). The pharmacologically active 4-hydroxycyclophosphamide metabolite of cyclophosphamide is first formed by phase I metabolism through cytochrome P450 enzymes and further converted to the phosphoramide mustard. Alterations in expression of drug metabolizing enzymes or transporters in leukocytes can affect the exposure of these cells to pharmacologically active components such as mycophenolic acid and 4-hydroxycyclophosphamide.

Drug transporters would be most important to characterize, since enhanced activity and/or expression of cellular efflux genes and their respective proteins relative to up- 
take would reduce the intracellular concentration of therapeutic entities. Decreased activity and/or expression of efflux genes relative to uptake would increase intracellular drug concentrations. For leukocyte metabolism processes, expression of drug metabolizing enzymes may modulate the exposure of the tissue to active (4-hydroxycyclophosphamide) versus inactive (mycophenolic acid glucuronide) pharmacologic moieties. Previous studies have described the presence of UGT mRNA in various solid organs (liver, kidney, intestine, lung, stomach, brain, breast, prostate, heart, adrenals, bladder, ovary, uterus, and testis) within rats and humans [1, 2, 3, 4]. Metabolism processes in leukocytes, generally, would be predicted to be less contributory than systemic metabolism. The peripheral blood cells have been largely ignored for assessment of drug metabolism genes and limited studies have reported mRNA expression of selected transporters and cytochrome P450s $[5,6,7]$. These studies reported limited correlation between expression in leukocytes and intestine and liver and altered expression in subsets of leukocytes [5, 6, 7]. However, the importance of leukocyte expression and function for drugs targeting these cells for their therapeutic effects was reported by Meaden et al. [8] employing ritonavir and saquinavir. The authors reported lower MRP1 expression and higher leukocyte accumulation of ritonavir and saquinavir. They also reported higher ritonavir accumulation and lower P-glycoprotein expression. There is currently limited information regarding expression of drug transporter genes or drug metabolizing genes in patients representing specific disease models or in selected tissues (such as leukocytes) that are the targeted pharmacological site of action.

Several exogenous and endogenous factors may be responsible for altering mRNA expression and subsequent exposure to therapeutic agents at their active site. Inducers of transport and metabolism pathways have been shown to concordantly increase activity and mRNA expression within hepatocytes [9]. mRNA expression of drug transporters has been reported to be affected by inflammatory diseases and conditions (e.g., rheumatoid arthritis, ulcerative colitis, ischemia-reperfusion injury) and direct exposure to inflammatory cytokines (e.g., TNF- $\alpha$, IL6) $[10,11,12,13]$. Gender specific effects on $U G T$ mRNA expression in tissues (liver, kidney, lung, intestine, brain, nose) have been documented in mice $[14,15]$. A genotype dependent down-regulation of mRNA expression and protein function in peripheral blood mononuclear cells has also been reported in humans, whereby wild-type and heterozygotes for the C3435T single nucleotide polymorphism in the multidrug resistance protein gene $(A B C B 1 ; M D R 1)$ exhibited less relative expression as compared to the homozygous variant genotype [16].

In order to incorporate clinical relevance to mRNA expression assessments, we were interested in evaluating leukocyte expression patterns of specific drug transport and metabolism genes known to be relevant in the disposition of mycophenolic acid and cyclophosphamide. Both of these compounds are clinically used in the treatment of glomerulonephritis secondary to systemic lupus erythematosus (SLE) or small vessel vasculitis (SVV). The drug transporter genes targeted in this study were $A B C B 1, A B C C 2, A B C G 2$, and SLCO1A2. The drug metabolism genes targeted were UGT1A7, UGT1A9, UGT2B7, $C Y P 2 C 9, C Y P 2 B 6$, and $C Y P 3 A 4$. The purpose of conducting this pilot study was to inform about how mRNA expression data representing transporter and metabolism genes is related to patient level data and pharmacokinetic responses in autoimmune-mediated glomerulonephritis being treated with either mycophenolate or cyclophosphamide.

\section{Material and methods}

\section{Subjects and specimens}

Patients with glomerulonephritis secondary to SLE $(\mathrm{n}=36)$ and SVV $(\mathrm{n}=35)$ who participated in prospective pharmacokinetic studies to evaluate mycophenolic acid [17, 18] and cyclophosphamide [19] had $15 \mathrm{~mL}$ of blood drawn into multiple ethylenediaminetetraacetic acid (EDTA) vacutainer tubes. The blood was obtained prior to administration of cyclophosphamide and mycophenolate. Leukocytes were isolated from blood by incubation (11 minutes) in a hypotonic red cell lysis buffer, followed by cen- 
trifugation and a wash with Hank's balanced salt solution (HBSS). The leukocytes were subsequently lysed in RNA Stat 60 solution and stored at $-70{ }^{\circ} \mathrm{C}$ for up to 2 weeks until processing. The study and consent forms were approved by the Biomedical Review Board at the University of North Carolina at Chapel Hill.

\section{mRNA isolation}

The mRNA isolation procedure consisted of adding $200 \mu \mathrm{L}$ chloroform for phase separation. The aqueous phase (containing the mRNA) was added to a solution of isopropanol and centrifuged. The pellet was then washed with $1 \mathrm{~mL} 75 \%$ ethanol, re-suspended in $100 \mu \mathrm{L}$ nuclease free water (Promega, Madison, WI, USA), and centrifuged. Four microliters RNA secure 25X (Ambion, Austin, TX, USA) were added to each sample. The RNeasy kit and protocol (Qiagen, Valencia, CA, USA) was used for the remainder of the mRNA preparation. Briefly, after adding Buffer RLT, $\beta$-Mercaptoethanol, and 100\% ethanol to the samples, the mRNA solution was applied to an RNeasy mini spin column for purification. mRNA was re-treated with RNA secure at 1X (Ambion) after the column elution. mRNA was quantified by evaluation of the absorbance at $260 \mathrm{~nm}$ and $280 \mathrm{~nm}$ using a spectrophotometer. The mRNA integrity was determined by visualization of the $28 \mathrm{~S}$ and $18 \mathrm{~S}$ mRNA bands using $0.5 \mu \mathrm{g}$ mRNA on a $1 \%$ agarose gel stained with Sybr Gold (Molecular Probes, Eugene, OR, USA). mRNA was stored at $-70{ }^{\circ} \mathrm{C}$.

\section{Evaluation of transcript levels}

An aliquot of each patient's mRNA was converted to cDNA via the High Capacity cDNA Reverse Transcription kit (Applied Biosystems). A $20 \mu \mathrm{L}$ reaction was prepared that included; $2 \mu \mathrm{L}$ of 10x RT Buffer; $0.8 \mu \mathrm{L}$ of $25 \mathrm{x}$ dNTP Mix $(100 \mathrm{mM}) ; 2 \mu \mathrm{L}$ of 10x RT Random Primers; $1 \mu \mathrm{L}$ of MultiScribe Reverse Transcriptase; $4.2 \mu \mathrm{L}$ of Nuclease-free water and $10 \mu \mathrm{L}$ of mRNA. The plate was placed in a thermal cycler under the profile; $25^{\circ} \mathrm{C}$ for 10 minutes, $37^{\circ} \mathrm{C}$ for 120 minutes, $85{ }^{\circ} \mathrm{C}$ for 5 minutes, and $4{ }^{\circ} \mathrm{C}$ for infinity.

Pre-designed assays containing primers and probes for the assessment of transcript levels of the targeted metabolizing enzymes (UGT1A7, UGT1A9, UGT2B7, CYP3A4, CY$P 2 C 9$, and CYP2B6) and transporters (ABCB1, $A B C C 2, A B C G 2$, and SLCO1A2); UGT1A7 (Hs02517015_s1), UGT2B7 (Hs02556232 s1), UGT1A9 (Hs02516855_sH), CYP3A4 (Hs00604506_M1), CYP2C9 (Hs00426397 $\mathrm{m1}), \quad C Y P 2 B 6$ (Hs00167937_g1), ABCC2 (Hs00166123_ml), ABCB1 (Hs00184500_ $\mathrm{m} 1), A B C G 2$ (Hs01053795_m1), and SLCO1A2 (Hs01072338_m1) were purchased from Applied Biosystems. Cytochrome C oxidase was used as the normalization (housekeeping) gene. The forward and reverse primers were designed using Primer Express software (Applied Biosystems). The forward primer (TGGCATCTGGAGGTGGTGTT) and reverse primer (GTCCAGTCCCTTTGCAGC) were purchased from Applied Biosystems. Sybr 1:400 was used as the probe in the cytochrome $\mathrm{c}$ oxidase assay (Molecular Probes, Leiden, Netherlands).

Taqman ${ }^{\circledR}$ PCR was performed on an Applied Biosystems PRISM 7900 HT sequence detection system (Applied Biosystems). The duplicate $10 \mu \mathrm{L}$ reactions were performed in MicroAmp Optical 384 well plates. For the commercial assays, the reaction mixture was composed of $40 \mathrm{ng}(4 \mu \mathrm{L})$ of cDNA; $0.5 \mu \mathrm{L}$ of 20x probe and primer (Applied Biosyste$\mathrm{ms}$ ), $0.5 \mu \mathrm{L}$ nuclease-free water, and $5 \mu \mathrm{L}$ of 2x Universal PCR Master Mix (Applied Biosystems). For the cytochrome $\mathrm{C}$ oxidase assay, the reaction mixture was composed of $40 \mathrm{ng}(4 \mu \mathrm{L})$ of cDNA; $0.1 \mu \mathrm{L}$ of $5 \mu \mathrm{M}$ forward primer; $0.1 \mu \mathrm{L}$ of $5 \mu \mathrm{M}$ reverse primer; $0.3 \mu \mathrm{L}$ of $1: 400$ dilution Sybr Green (Molecular Probes, Leiden Netherlands); $0.5 \mu \mathrm{L}$ nuclease-free water, $5 \mu \mathrm{L}$ of $2 \mathrm{x}$ Universal PCR Master Mix (Applied Biosystems). The thermal cycling conditions were; $50{ }^{\circ} \mathrm{C}$ for 2 minutes, $95{ }^{\circ} \mathrm{C}$ for 10 minutes, $95^{\circ} \mathrm{C}$ for 15 seconds in 50 cycles, $60^{\circ} \mathrm{C}$ for 1 hour.

\section{Genotype assessments}

A $5 \mathrm{~mL}$ whole blood sample was collected into an EDTA containing vacutainer tube and genomic DNA was isolated using a 
Table 1. Demographics of glomerulonephritis patients. Data presented as $\mathrm{n}$ (percentage).

\begin{tabular}{|c|c|c|}
\hline & $\begin{array}{l}\text { Small vessel vasculitis } \\
(\mathrm{n}=35)\end{array}$ & $\begin{array}{c}\text { Systemic lupus } \\
\text { erythematosus }(n=36)\end{array}$ \\
\hline \multicolumn{3}{|l|}{ Race (\%) } \\
\hline Caucasian & $25(71 \%)$ & $8(22 \%)$ \\
\hline Non-Caucasian & $10(29 \%)$ & $28(78 \%)$ \\
\hline Gender (\%female) & $20(57 \%)$ & $28(78 \%)$ \\
\hline \multicolumn{3}{|l|}{ Treatment (\%) } \\
\hline Cyclophosphamide & $7(20 \%)$ & $15(42 \%)$ \\
\hline Mycophenolic acid & $28(80 \%)$ & $21(58 \%)$ \\
\hline
\end{tabular}

Flexigene Qiagen kit (Qiagen). Genotyping was conducted for several published $U G T$ single nucleotide polymorphisms (UGT1A9, UGT1A7, and UGT2B7) relevant for alterations in metabolism [20, 21, 22, 23, 24], and $A B C B 1 / M D R 1$ relevant for transport of mycophenolic acid [25], as previously described [26]. Genotyping was also conducted for polymorphisms in some cytochrome $\mathrm{P} 450$ genes (CYP2B6, CYP3A4, CYP2C9) relevant for alterations in cyclophosphamide metabolism [27, 28, 29]. Genotyping assessments for CYP2B6 C1459T (c30634242) and CYP2B6 G516T (c22275631) were conducted using commercially available assays (Applied Biosystems). Allelic discrimination was assessed for all Applied Biosystems products as previously described [26]. Genotypes for polymorphisms in $A B C C 2, A B C G 2$ and $S L C O 1 A 2$ were not assessed.

\section{Data analyses}

Stored mRNA from healthy controls; HC $(\mathrm{n}=10)$, untreated SLE nephritis patients; LC $(n=5)$ and untreated SVV with nephritis; $\mathrm{VC}(\mathrm{n}=5)$ patients were used as study and disease controls, respectively. $\mathrm{Ct}, \Delta \mathrm{Ct}, \Delta \Delta \mathrm{Ct}$, and $2^{\wedge}-\Delta \Delta \mathrm{Ct}$ were calculated [30]. The $\mathrm{Ct}$ values (the fractional cycle at which the fluorescence intensity equals the threshold fluorescence; inversely related to the abundance of transcript in a sample) were computed for each sample. Subsequently $\Delta \mathrm{Ct}$ values were calculated for each sample by subtracting the $\mathrm{Ct}$ value for the housekeeping gene (cytochrome $\mathrm{C}$ oxidase) from the $\mathrm{Ct}$ value for the gene of interest. In order to calculate foldchange, the $2^{\wedge}-\Delta \Delta \mathrm{Ct}$ were computed. The $\Delta \Delta \mathrm{Ct}$ values were calculated by subtracting the $\Delta \mathrm{Ct}$ of a selected healthy control from the $\Delta \mathrm{Ct}$ of each discrete sample. The foldchange was calculated by dividing the individual $2^{\wedge}-\Delta \Delta C$ t values by the average of the $2^{\wedge}-\Delta \Delta \mathrm{Ct}$ values for healthy control samples.

Transcript fold-change in each of the five groups (SVV, VC, SLE, LC, HC) were computed and recorded as medians, and mean \pm standard deviation. Significant differences between the median fold-change values among patient groups were determined using Kruskal Wallis nonparametric ANOVA. A post-ANOVA Dunn's Multiple Comparison's test was used to determine differences in median transcript expression. Patient level data that was evaluated for relationships with transcript fold-change were: disease (SVV vs. SLE), treatment (cyclophosphamide vs. mycophenolate), gender, race (Caucasian vs. non-Caucasian), and genotype (UGT1A7, UGT1A9, UGT2B7, $C Y P 2 C 9, C Y P 3 A 4, C Y P 2 B 6$, and $A B C B 1$ ). The expression values were converted to the $\log 10$ to enable a normal distribution so that linear regression could be used to evaluate these former relationships. Spearman correlation analysis was used to evaluate relationships between fold-change expression values by disease, genotypes, treatments, gender, and race. Spearman correlation analyses were also conducted to evaluate for relationships between continuous mycophenolic acid and cyclophosphamide pharmacokinetic variables $[17,18,19]$; area under the plasma concentration time curve (AUC), trough plasma concentration (Ctr), apparent oral clearance (mycophenolic acid), systemic clearance (cyclophosphamide), renal clearance, and transcript expression. Wilcoxon two-sample tests were used to assess for relationships of SLCO1A2 transcript expression between gender, race, disease, and treatment. p-values of $<0.05$ were considered statistically significant. Statistical analyses were performed using InStat v3.0 (GraphPad, San Diego, CA, USA) and SAS Statistical Software, Version 9.1 (SAS Institute, Inc., Cary, NC, USA).

\section{Results}

The description of SLE and SVV study subjects who donated blood for gene transcript analyses are provided in Table 1 . This 
Table 2. Fold-change transcript values in the evaluated groups (mean $\pm S D$ ).

\begin{tabular}{|l|c|c|c|c|c|}
\hline & SVV $(n=35)$ & $\begin{array}{c}\text { SVV-control } \\
(n=5)\end{array}$ & SLE $(n=36)$ & $\begin{array}{c}\text { SLE-control } \\
(n=5)\end{array}$ & HC $(n=10)$ \\
\hline UGT1A9 & $0.98 \pm 2.24$ & NA & $0.62 \pm 1.27$ & $0.34 \pm 0.27$ & $0.94 \pm 1.73$ \\
\hline UGT2B7 & $2.46 \pm 6.38$ & $0.52 \pm 0$ & $2.13 \pm 4.87$ & $1.35 \pm 1.78$ & $1.00 \pm 1.64$ \\
\hline UGT1A7 & $0.17 \pm 0.42^{\mathrm{a}}$ & $0.27 \pm 0$ & $0.03 \pm 0.1^{\mathrm{b}}$ & $0.22 \pm 0.21$ & $0.79 \pm 2.02$ \\
\hline CYP2B6 & $0.50 \pm 0.57$ & $0.15 \pm 0.12$ & $1.49 \pm 2.55$ & $0.50 \pm 0.62$ & $1.00 \pm 0.99$ \\
\hline$A B C B 1$ & $0.65 \pm 0.96$ & $0.54 \pm 0.6$ & $0.33 \pm 0.21^{\mathrm{c}}$ & $0.45 \pm 0.31$ & $1.00 \pm 0.82$ \\
\hline$A B C C 2$ & $1.06 \pm 1.11^{\mathrm{d}}$ & $2.02 \pm 1.13$ & $1.35 \pm 1.21$ & $1.60 \pm 1.08$ & $1.00 \pm 0.41$ \\
\hline ABCG2 & $0.17 \pm 0.14^{\mathrm{e}}$ & $0.01 \pm 0$ & $0.31 \pm 0.33$ & $0.10 \pm 0.07$ & $1.00 \pm 1.82$ \\
\hline SLCO1A2 & $1.45 \pm 3.68$ & NA & $0.47 \pm 0.75$ & $0.01 \pm 0$ & $0.84 \pm 0.99$ \\
\hline
\end{tabular}

aSV < HC; $p<0.05$; ${ }^{\text {bSLE }}<\mathrm{HC}$; $\mathrm{p}<0.05$; ' $\mathrm{SLE}<\mathrm{HC}$; $\mathrm{p}<0.05$; ${ }^{\mathrm{d}} \mathrm{SV}$ < SVV-control; $\mathrm{p}=0.05$; e $\mathrm{SVV}<\mathrm{HC}$; $\mathrm{p}<0.05$. $A B C B 1$ : multidrug resistance protein; $A B C C 2$ : multidrug resistance-associated protein; $A B C G 2$ : breast cancer resistance protein; ANCA: antineutrophil cytoplasmic antibody; CYP: cytochrome P450; HC: healthy control; NA = not applicable; SLCO1A2: organic anion transporting polypeptide; SLE: systemic lupus erythematosus; SVV = small vessel vasculitis; UGT = uridine diphosphate glucuronosyltransferase.

information was not available (demographics) or did not apply (treatment) to the three control groups. The transcripts of transporter genes ( $A B C B 1, A B C G 2$, and $A B C C 2$ ) were expressed in the leukocytes of $92-98 \%$ of subjects. By contrast, the transcript of SLCO1A2 was expressed in only $50 \%$ of subjects. Regarding the drug metabolizing enzyme genes, the transcripts of UGT1A9, $U G T 1 A 7$, and $U G T 2 B 7$ were expressed in $\sim 50 \%$ of subjects, while the CYP $2 B 6$ transcript was expressed in $94 \%$ of subjects. The $C Y P 3 A 4$ and $C Y P 2 C 9$ genes were not appreciably expressed in the leukocytes of the evaluated subjects. Fold-change values for each gene in each patient group (SVV, VC, $\mathrm{SLE}, \mathrm{LC}, \mathrm{HC}$ ) are recorded as mean $\pm \mathrm{SD}$ in Table 2. Significant differences were noted in expression of UGT1A7, $A B C B 1$, $A B C G 2$, and $A B C C 2$ across the evaluated patient populations. Regarding UGT1A7, the SVV $(0.17 \pm 0.42 ; \mathrm{p}<0.05)$ and SLE $(0.03 \pm 0.1 ; \mathrm{p}<0.05)$ groups had statistically lower expression values than the $\mathrm{HC}$ subjects $(0.79 \pm 2.02)$. For $A B C B 1$, the SLE group had significantly lower expression values $(0.33 \pm 0.21 ; \mathrm{p}<0.05)$ than the $\mathrm{HC}$ group $(1 \pm 0.82)$. For the $A B C G 2$ gene, the SVV group had lower mean expression values $(0.17 \pm 0.14 ; \mathrm{p}<0.05)$ than the HC subjects $(1 \pm 1.82)$. Differences in expression of $A B C C 2$ approached statistical significance, with the VC patients $(2.02 \pm 1.13)$ exhibiting higher expression than the SVV patients $(1.06 \pm 1.11 ; \mathrm{p}=0.05)$.
Table 3. Genotype frequency distributions (frequency $(n))$.

\begin{tabular}{|l|c|c|}
\hline \multirow{2}{*}{ UGT1A7 } & \multicolumn{2}{|c|}{ SLE and SVV patients } \\
\hline \multirow{2}{*}{ T622C } & $\mathrm{T} / \mathrm{T}$ & $0.53(35)$ \\
\cline { 2 - 3 } & $\mathrm{T} / \mathrm{C}$ & $0.42(28)$ \\
\cline { 2 - 3 } & $\mathrm{C} / \mathrm{C}$ & $0.05(3)$ \\
\hline UGT2B7 & \multicolumn{2}{|c|}{} \\
\hline C802T & $\mathrm{C} / \mathrm{C}$ & $0.39(26)$ \\
\cline { 2 - 3 } & $\mathrm{C} / \mathrm{T}$ & $0.42(28)$ \\
\cline { 2 - 3 } & $\mathrm{T} / \mathrm{T}$ & $0.19(13)$ \\
\hline CYP2B6 & \multicolumn{2}{|c|}{} \\
\hline C1459T & $\mathrm{C} / \mathrm{C}$ & $0.82(55)$ \\
\cline { 2 - 3 } & $\mathrm{C} / \mathrm{T}$ & $0.15(10)$ \\
\cline { 2 - 3 } & $\mathrm{T} / \mathrm{T}$ & $0.03(2)$ \\
\hline \multirow{3}{*}{ G516T } & $\mathrm{G} / \mathrm{G}$ & $0.49(33)$ \\
\cline { 2 - 3 } & $\mathrm{G} / \mathrm{T}$ & $0.43(29)$ \\
\cline { 2 - 3 } & $\mathrm{T} / \mathrm{T}$ & $0.08(5)$ \\
\hline ABCB1 & \multicolumn{2}{|c|}{} \\
\hline C3435T & $\mathrm{C} / \mathrm{C}$ & $0.34(23)$ \\
\cline { 2 - 3 } & $\mathrm{C} / \mathrm{T}$ & $0.55(37)$ \\
\cline { 2 - 3 } & $\mathrm{T} / \mathrm{T}$ & $0.11(7)$ \\
\hline C1236T & $\mathrm{C} / \mathrm{C}$ & $0.43(29)$ \\
\cline { 2 - 3 } & $\mathrm{C} / \mathrm{T}$ & $0.49(33)$ \\
\cline { 2 - 3 } & $\mathrm{T} / \mathrm{T}$ & $0.08(5)$ \\
\hline
\end{tabular}

$A B C B 1=$ multidrug resistance protein; $C Y P=$ cytochrome P450; UGT = uridine-glucuronosyltransferase.

Genotype frequencies for the UGTIA7, $U G T 2 B 7, A B C B 1$, and $C Y P 2 B 6$ single nucleotide polymorphisms evaluated in the 67 treated SLE and SVV patients are shown in Table 3. Genotype frequencies for all evaluated polymorphisms were in Hardy-Weinberg equilibrium. Genotype analyses are not re- 
Table 4. Relationships between transcript expression and patient-level data in subjects with systemic lupus erythematosus and small vessel vasculitis.

\begin{tabular}{|l|l|c|c|}
\hline $\begin{array}{l}\text { Transcript } \\
\text { variable }\end{array}$ & Patient-level variable & $\begin{array}{c}\text { Parameter } \\
\text { estimate }\end{array}$ & p-value \\
\hline ABCB1 & Gender & 0.07 & 0.542 \\
\cline { 2 - 4 } & Race & 0.061 & 0.558 \\
\cline { 2 - 4 } & Treatment & -0.049 & 0.66 \\
\cline { 2 - 4 } & Disease & 0.152 & 0.144 \\
\cline { 2 - 4 } & ABCB1 C3435T genotype & -0.194 & 0.078 \\
\cline { 2 - 4 } & ABCB1 C1236T genotype & -0.092 & 0.385 \\
\hline \multirow{5}{*}{ ABCC2 } & Gender & 0.113 & 0.203 \\
\cline { 2 - 4 } & Race & -0.157 & 0.049 \\
\cline { 2 - 4 } & Treatment & 0.113 & 0.184 \\
\cline { 2 - 4 } & Disease & -0.141 & 0.078 \\
\hline \multirow{5}{*}{ ABCG2 } & Gender & 0.224 & 0.093 \\
\cline { 2 - 4 } & Race & -0.07 & 0.562 \\
\cline { 2 - 4 } & Treatment & 0.058 & 0.657 \\
\cline { 2 - 4 } & Disease & 0.04 & 0.831 \\
\hline CYP2B6 & Gender & 0.14 & 0.531 \\
\cline { 2 - 4 } & Race & -0.196 & 0.33 \\
\cline { 2 - 4 } & Treatment & 0.537 & 0.01 \\
\cline { 2 - 4 } & Disease & -0.142 & 0.483 \\
\cline { 2 - 4 } & CYP2B6 A785G genotype & 0.049 & 0.906 \\
\cline { 2 - 4 } & CYP2B6 C1459T genotype & -0.166 & 0.533 \\
\cline { 2 - 4 } & CYP2B6 G516T genotype & 0.083 & 0.68 \\
\hline
\end{tabular}

Transcript expression values were log 10 transformed for analyses. p-values $<0.05$ are italicized.
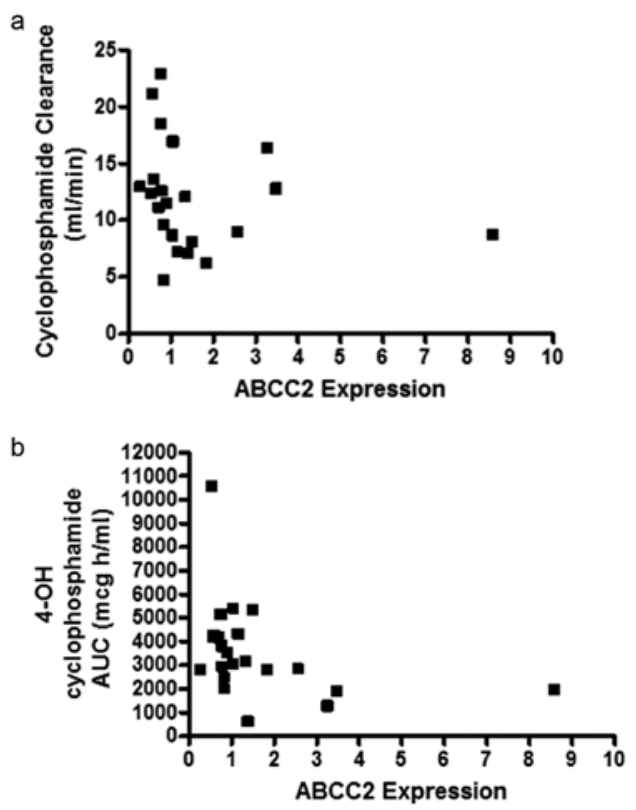

Figure 1. a: Correlation between leukocyte ABCC2 mRNA expression and cyclophosphamide clearance. A significant negative correlation was noted between ABCC2 mRNA expression and cyclophosphamide clearance ; $r=-0.4263,95 \%$ C.I. -0.7252 to $0.007672, p=0.0479$. b: Correlation between leukocyte ABCC2 mRNA expression and 4-OH cyclophosphamide clearance. A significant negative correlation was noted between $A B C C 2$ mRNA expression and 4-OH cyclophosphamide clearance ; $r=-0.4850,95 \%$ C.I. -0.7585 to $-0.06640, p=0.0221$. were planned due to their extremely low frequency in this glomerulonephritis population.

Several important findings $(p<0.05)$ resulted from the evaluation of the relationships between transcript expression and patient-level data (Table 4). However, none of the relationships resulted in $\mathrm{R}^{2}$ values of greater than 0.10 secondary to the dichotomous nature of the patient-level data. Among the SVV and SLE groups receiving treatment with either mycophenolate or cyclophosphamide, $A B C C 2$ expression was different by race $(1.26 \pm 1.82$ Caucasian vs. $1.37 \pm 0.86$ non-Caucasian; $\mathrm{p}=0.049)$; $C Y P 2 B 6$ expression was different by treatment $(2.07 \pm 2.94$ cyclophosphamide vs. $0.45 \pm 0.5$ mycophenolate; $\mathrm{p}=0.01)$. Results of borderline significance $(0.05<\mathrm{p}<0.10)$ were $A B C B 1$ expression by $A B C B 1 \quad C 3435 T$ genotype $(0.43 \pm 0.55$ wildtype vs. $0.63 \pm 0.88$ variants; $\mathrm{p}=0.076), A B C C 2$ expression by disease type $(1.20 \pm 1.5 \mathrm{SVV}$ vs. $1.43 \pm 1.29$ SLE; $\mathrm{p}=0.078)$, and $A B C G 2$ expression within SLE patients by gender $(0.34 \pm 0.34$ female versus $0.11 \pm 0.07$ male; $\mathrm{p}=0.074)$. Assessment of relationships between $U G T$ or SLCO1A2 expression and patient-level variables were not attempted secondary to the higher percentage of subjects with absent transcript in leukocytes. Additionally, too few subjects exhibited the evaluated single nucleotide polymorphisms in the UGT1A9 gene to enable evaluation with transcript expression.

Assessments of relationships between transcript expression and pharmacokinetic parameters for mycophenolic acid and cyclophosphamide were evaluated to ascertain whether overall dispositional effects were demonstrated. Significant negative correlations were noted between $A B C C 2$ expression and cyclophosphamide clearance ( $\mathrm{r}-0.426$; $\mathrm{p}=0.048)$, and 4-hydroxycyclophosphamide AUC ( $r-0.4850 ; p=0.0221$ ) (Figure 1). No significant correlations were noted for mycophenolate pharmacokinetic parameters and mRNA expression data. 


\section{Discussion}

The current study is the first to describe expression of drug metabolizing enzyme and drug transporter transcripts in the leukocytes of patients with kidney disease secondary to immune-mediated glomerulonephritis. This research is relevant as therapies for the treatment of glomerulonephritis are primarily directed toward the peripheral blood leukocyte population. This study selectively assessed only those genes thought to be involved in the transport and metabolism of mycophenolate and cyclophosphamide, the two primary treatments in glomerulonephritis. Our studies demonstrated reasonable leukocyte expression of transporter transcripts ( $A B C C 2, A B C B 1, A B C G 2 ; 90 \%$ of patients and $S L C O 1 A 2 ; 50 \%$ of patients) in the blood of glomerulonephritis patients. Reasonable expression of leukocyte $U G T$ transcripts (UGT1A9, UGT1A7, and UGT2B7; 50\% of patients), and CYP2B6 ( $>90 \%$ of patients) were noted as well. CYP $3 A 4$ and $C Y P 2 C 9$ expression was virtually absent.

Since transporters on leukocytes have been reported to contribute to the intracellular concentrations of drugs, we were interested in evaluating the expression of drug transporters on the leukocytes of patients with glomerulonephritis [31, 32, 33, 34]. Differences in mean drug transporter transcript expression among the subject groups were found in the present study. Healthy controls had a higher $A B C B 1$ expression than SLE patients, and a higher $A B C G 2$ expression than SVV patients. These findings could contribute to higher intra-leukocyte concentrations of substrates transported by P-glycoprotein and breast cancer resistance associated protein in patients with SLE and SVV, respectively. We plan to assess intracellular concentrations of drugs in future studies that employ patients with glomerulonephritis. Albermann et al. [5], previously reported the relative order of gene expression for $\mathrm{ABC}$-transporters in peripheral blood mononuclear cells as $A B C$ $C 1>A B C G 2>A B C B 1>A B C C 2$. The relative order of magnitude in transcript expression for glomerulonephritis patients was $A B C$ $C 2>S L C O 1 A 2>A B C B 1=A B C G 2$ for SLE and $S L C O 1 A 2>A B C C 2>A B C B 1>A B C G 2$ for SVV. This data demonstrates that the MRP2 and OATP transporters (most perti- nent to overall disposition of mycophenolic acid) have the highest expressed transcripts within the leukocytes of SLE and SVV patients. Mycophenolic acid is a substrate of P-glycoprotein [25, 35, 36], and BCRP [37], the glucuronide metabolite is a substrate for MRP2 [38], and glucocorticoids are known substrates for P-glycoprotein [39, 40]. In vitro studies that assess the role of transporters of mycophenolic acid and its metabolites and leukocyte disposition will be assessed in our future studies.

Our evaluations regarding drug metabolism genes demonstrated that healthy controls had a higher expression of UGTIA7 relative to SVV and SLE patients. Since mycophenolic acid is a substrate for UGT1A7 [41] and SLE and SVV patients have reduced UGT1A7 transcript expression relative to healthy controls, the glomerulonephritis patients would be predicted to have a lower metabolism of mycophenolic acid through UGT1A7 within the leukocytes. The affinity of mycophenolic acid for UGT1A7 is greater than the affinity for UGT1A9 [41], another common metabolizing enzyme, however, the overall relative contribution of UGT1A7 to mycophenolic acid metabolism in various tissues, including leukocytes has not been reported.

In order to provide clinical relevance to our work, we were interested in exploring the effects of patient-level factors on transcript expression in the SLE and SVV patients. These factors (treatment, gender, race, and genotype) were included as existing publications supported their evaluations $[9,14,16$, $42,43,44]$. Treatment-related differences in expression were assessed in mycophenolatevs. cyclophosphamide-treated patients. Our results showed that cyclophosphamide-treated glomerulonephritis patients had a 4-fold higher expression of CYP2B6 $(2.07 \pm 2.94$ vs. $0.45 \pm 0.5 ; \mathrm{p}=0.01)$ than mycophenolate-treated patients. While it is tempting to attribute this finding to induction of gene transcription by cyclophosphamide, this scenario is unlikely for several reasons including the fact that previous doses had been administered at least 30 days prior, doses were lower $\left(0.8 \pm 0.2 \mathrm{~g} / \mathrm{m}^{2}\right)$ than reported for enzyme induction [45], and blood was obtained prior to and not after the next planned dose. For SLE patients, higher expression of $A B C C 2$ 
and $A B C G 2$ would be predicted to reduce intracellular exposure to mycophenolic acid as compared to SVV patients. While we did not prospectively measure this directly, our previous pharmacokinetic publications [17, 18], do support higher systemic (extracellular) exposures in SLE vs. SVV patients. Exposures to other concurrent treatments, however, can influence expression of drug metabolizing enzyme transcripts $[9,44,46]$. Glucocorticoids were prescribed in $36 \%$ of our mycophenolate-treated and $86 \%$ of our cyclophosphamide-treated patients. Based on previous data from glucocorticoid exposures [9], induction of $A B C C 2$ and $S L C O 1 A 2$ can occur. The finding of high expression of both the $A B C C 2$ and $S L C O 1 A 2$ transcripts in our SLE and SVV patients suggests an influence from glucocorticoid exposure.

Since recent publications have reported gender divergent effects on $U G T$ transcript and tissue expression in mice $[14,15]$ and reduced activity of UGTs females [47], we wanted to evaluate the gender-stratified expression of our evaluated genes in the glomerulonephritis population. While none of these assessments reached statistical significance, a trend was noted in female patients having 3-fold higher expression of the $A B C G 2$ transcript than males. This finding is interesting as females comprise the majority of SLE patients, and higher expression of $A B C G 2$ was found in the SLE patients; implying that a disease-gender interaction may be confounding. Regarding our assessments of the effects of race, the expression of $A B C C 2$ in leukocytes was found to be lower in Caucasian than non-Caucasian SLE and SVV patients. The non-Caucasian group comprised the majority of SLE patients and these patients were disproportionately African-American. African-American SLE patients are known to have worse treatment related outcomes [48]. We plan to explore the relationships between intracellular concentrations of drug treatments, expression of transporters, and treatment outcomes in future studies. In the current study, we found higher $A B C B 1$ leukocyte expression in patients who exhibited the $\mathrm{C} / \mathrm{T}$ and $\mathrm{T} / \mathrm{T}$ genotypes as compared to the wildtype $(\mathrm{C} / \mathrm{C})$ genotype, a finding consistent with the literature $[16,49]$. The role of genotype on transcript expression of $A B C B 1$ was recently reported in a study that isolated peripheral blood cells from healthy subjects and incubated them with lipopolysaccharide (LPS) [16]. However, the published data concerning P-glycoprotein activity in patients by genotype for the $A B C B 1 C 3435 T$ polymorphism are conflicting [49].

Since expression of transporters on leukocytes has been reported to alter intracellular pharmacokinetics, we wanted to evaluate the correlation between mycophenolic acid and cyclophosphamide clearance and/or exposure parameters and transcript expression. Since we did not evaluate intracellular concentrations of drugs, systemic clearance and/or exposure data was used. Significant negative correlations were found between $A B C C 2$ expression with cyclophosphamide clearance and with 4-hydroxycyclophosphamide AUC. Based on our pilot study, this could imply that enhanced exposure to 4-hydroxycyclophosphamide would be predicted when low $A B C C 2$ transcript expression is present. Previously published data has suggested that MRP2, along with MRP4 and BCRP2 contribute to the disposition of 4-hydroxycyclophosphamide [50], providing some physiological relevance to our pilot study findings. The protein of $A B C C 2$, e.g., MRP2 is localized to the apical (bile cannilicular) membrane of liver and serves to efflux organic anions from hepatocytes. Decreased MRP2 protein in liver would result in reduced loss of 4-hydroxycyclophosphamide from the hepatocytes and enhanced opportunity for efflux through MRP4 at the hepatocyte basolateral membrane, with increased AUC.

\section{Conclusions}

The current study showed differential expression patterns of drug metabolizing enzyme and transporter transcripts in patients with active glomerulonephritis as compared to healthy subjects and disease control subjects without active glomerulonephritis. Treatment and patient-specific variables were associated with significant differences in expression of drug metabolism and transport genes. This study adds to the sparse literature describing the transcript expression of drug transporters in leukocytes and focuses on a disease in which patients receive therapies 
targeted to the leukocytes. This basic knowledge is required as transcript and ultimately protein expression of drug metabolizing enzymes and transporters can modulate the exposure to active pharmacologic moieties in the blood and tissues. The data from this pilot study will guide future investigations into mechanisms for altered treatment responses. It will be necessary to validate the current study's findings in a larger cohort of patients. Large prospectively designed studies with serial expression profiles will be necessary to validate cause and affect relationships. The implications of altered local metabolism and transport in leukocytes may be important in the treatments of other autoimmune diseases and transplantation.

\section{Funding}

This research was funded by the National Institutes of Health 5K23DK64888, General Clinical Research Centers program of the Division of Research Resources, National Institutes of Health RR00046, Clinical and Translational Science Award U54RR024383, and American College of Clinical Pharmacy Research Institute's Frontier's Award.

\section{Conflict of interest}

No conflicts of interest by any of the authors.

\section{References}

[1] Webb LJ, Miles KK, Auyeung DJ, Kessler FK, Ritter $J K$. Analysis of substrate specificities and tissue expression of rat UDP-glucuronosyltransferases UGT1A7 and UGT1A8. Drug Metab Dispos. 2005; 33: 77-82.CrossRef PubMed

[2] Shelby $M K$, Cherrington NJ, Vansell NR, Klaassen $C D$. Tissue mRNA expression of the rat UDPglucuronosyltransferase gene family. Drug Metab Dispos. 2003; 31: 326-333. CrossRef PubMed

[3] Ohno $S$, Nakajin $S$. Determination of mRNA expression of human UDP-glucuronosyltransferases and application for localization in various human tissues by real-time reverse transcriptase-polymerase chain reaction. Drug Metab Dispos. 2009; 37: 32-40. CrossRef PubMed

[4] Nakamura A, Nakajima M, Yamanaka H, Fujiwara $R$, Yokoi T. Expression of UGT1A and UGT2B mRNA in human normal tissues and various cell lines. Drug Metab Dispos. 2008; 36: 1461-1464. CrossRef PubMed

[5] Albermann N, Schmitz-Winnenthal FH, Z'graggen $K$, Volk C, Hoffmann MM, Haefeli WE, Weiss J. Expression of the drug transporters MDR1/ ABCB1, MRP1/ABCC1, MRP2/ABCC2, BCRP/ $\mathrm{ABCG} 2$, and PXR in peripheral blood mononuclear cells and their relationship with the expression in intestine and liver. Biochem Pharmacol. 2005; 70: 949-958.CrossRef PubMed

[6] Moon YJ, Zhang S, Morris ME. Real-time quantitative polymerase chain reaction for BCRP, MDR1, and MRP1 mRNA levels in lymphocytes and monocytes. Acta Haematol. 2007; 118: 169-175. CrossRef PubMed

[7] Furukawa M, Nishimura M, Ogino D, Chiba R, Ikai I, Ueda N, Naito S, Kuribayashi S, Moustafa MA, Uchida T, Sawada H, Kamataki T, Funae Y, Fukumoto $M$. Cytochrome p450 gene expression levels in peripheral blood mononuclear cells in comparison with the liver. Cancer Sci. 2004; 95: 520-529. CrossRef PubMed

[8] Meaden ER, Hoggard PG, Newton P, Tjia JF, Aldam D, Cornforth D, Lloyd J, Williams I, Back DJ, Khoo SH. P-glycoprotein and MRP1 expression and reduced ritonavir and saquinavir accumulation in HIV-infected individuals. J Antimicrob Chemother. 2002; 50: 583-588. CrossRef PubMed

[9] Richert L, Tuschl G, Abadie C, Blanchard N, Pekthong D, Mantion G, Weber JC, Mueller SO. Use of mRNA expression to detect the induction of drug metabolising enzymes in rat and human hepatocytes. Toxicol Appl Pharmacol. 2009; 235 : 86-96.CrossRef PubMed

[10] Uno $S$, Uraki $M$, Ito A, Shinozaki Y, Yamada A, Kawase A, Iwaki $M$. Changes in mRNA expression of ABC and SLC transporters in liver and intestines of the adjuvant-induced arthritis rat. Biopharm Drug Dispos. 2009; 30: 49-54.Cross$\underline{\text { Ref PubMed }}$

[11] Hirano T, Onda K, Toma T, Miyaoka M, Moriyasu $F$, Oka $K$. MDR1 mRNA expressions in peripheral blood mononuclear cells of patients with ulcerative colitis in relation to glucocorticoid administration. J Clin Pharmacol. 2004; 44: 481-486. CrossRef PubMed

[12] Tanaka Y, Chen C, Maher JM, Klaassen CD. Ischemia-reperfusion of rat livers decreases liver and increases kidney multidrug resistance associated protein 2 (Mrp2). Toxicol Sci. 2008; 101: 171-178. CrossRef PubMed

[13] Vee ML, Lecureur V, Stieger B, Fardel O. Regulation of drug transporter expression in human hepatocytes exposed to the proinflammatory cytokines tumor necrosis factor-alpha or interleukin-6. Drug Metab Dispos. 2009; 37: 685-693.CrossRef PubMed

[14] Buckley DB, Klaassen CD. Tissue- and genderspecific mRNA expression of UDP-glucuronosyltransferases (UGTs) in mice. Drug Metab Dispos. 2007; 35: 121-127. CrossRef PubMed

[15] Buckley DB, Klaassen CD. Mechanism of genderdivergent UDP-glucuronosyltransferase mRNA expression in mouse liver and kidney. Drug Metab Dispos. 2009; 37: 834-840.CrossRef PubMed

[16] Markova S, Nakamura T, Sakaeda T, Makimoto H, Uchiyama H, Okamura N, Okumura K. Genotypedependent down-regulation of gene expression and 
function of MDR1 in human peripheral blood mononuclear cells under acute inflammation. Drug Metab Pharmacokinet. 2006; 21: 194-200.CrossRef PubMed

[17] Joy MS, Hilliard T, Hu Y, Hogan SL, Dooley MA, Falk RJ, Smith PC. Pharmacokinetics of mycophenolic acid in patients with lupus nephritis. Pharmacotherapy. 2009; 29: 7-16. CrossRef PubMed

[18] Joy MS, Hilliard T, Hu Y, Hogan SL, Wang J, Falk $R J$, Smith $P C$. Influence of clinical and demographic variables on mycophenolic acid pharmacokinetics in antineutrophil cytoplasmic antibody-associated vasculitis. Ann Pharmacother. 2009; 43: 1020-1027.CrossRef PubMed

[19] Joy MS, La M, Wang J, Bridges AS, Hu Y, Hogan SL, Frye RF, Blaisdell J, Goldstein JA, Dooley $M A$, Brouwer KL, Falk RJ. Cyclophosphamide and 4-hydroxycyclophosphamide pharmacokinetics in patients with glomerulonephritis secondary to lupus and small vessel vasculitis. Br J Clin Pharmacol. 2012; 74: 445-455.CrossRef PubMed

[20] Lévesque E, Delage R, Benoit-Biancamano $M O$ Caron P, Bernard O, Couture F, Guillemette C. The impact of UGT1A8, UGT1A9, and UGT2B7 genetic polymorphisms on the pharmacokinetic profile of mycophenolic acid after a single oral dose in healthy volunteers. Clin Pharmacol Ther. 2007; 81: 392-400.CrossRef PubMed

[21] Lévesque E, Benoit-Biancamano MO, Delage R, Couture F, Guillemette C. Pharmacokinetics of mycophenolate mofetil and its glucuronide metabolites in healthy volunteers. Pharmacogenomics. 2008; 9: 869-879.CrossRef PubMed

[22] Bernard O, Tojcic J, Journault K, Perusse L, Guillemette $C$. Influence of nonsynonymous polymorphisms of UGT1A8 and UGT2B7 metabolizing enzymes on the formation of phenolic and acyl glucuronides of mycophenolic acid. Drug Metab Dispos. 2006; 34: 1539-1545.CrossRef PubMed

[23] Kagaya H, Inoue K, Miura M, Satoh S, Saito M, Tada H, Habuchi T, Suzuki T. Influence of UGT1A8 and UGT2B7 genetic polymorphisms on mycophenolic acid pharmacokinetics in Japanese renal transplant recipients. Eur J Clin Pharmacol. 2007; 63: 279-288.CrossRef PubMed

[24] Kuypers DR, Naesens M, Vermeire S, Vanrenterghem $Y$. The impact of uridine diphosphate-glucuronosyltransferase 1A9 (UGT1A9) gene promoter region single-nucleotide polymorphisms T-275A and C-2152T on early mycophenolic acid dose-interval exposure in de novo renal allograft recipients. Clin Pharmacol Ther. 2005; 78: 351-361. CrossRef PubMed

[25] Wang J, Figurski M, Shaw LM, Burckart GJ. The impact of P-glycoprotein and Mrp2 on mycophenolic acid levels in mice. Transpl Immunol. 2008; 19: 192-196.CrossRef PubMed

[26] Joy MS, Boyette T, Hu Y, Wang J, La M, Hogan SL, Stewart PW, Falk RJ, Dooley MA, Smith PC. Effects of uridine diphosphate glucuronosyltransferase $2 \mathrm{~B} 7$ and $1 \mathrm{~A} 7$ pharmacogenomics and patient clinical parameters on steady-state mycophenolic acid pharmacokinetics in glomerulonephritis. Eur J Clin Pharmacol. 2010; 66: 1119-1130. CrossRef PubMed
[27] Chen CS, Lin JT, Goss KA, He YA, Halpert JR, Waxman DJ. Activation of the anticancer prodrugs cyclophosphamide and ifosfamide: identification of cytochrome P450 2B enzymes and sitespecific mutants with improved enzyme kinetics. Mol Pharmacol. 2004; 65: 1278-1285. CrossRef PubMed

[28] Huang Z, Roy P, Waxman DJ. Role of human liver microsomal CYP3A4 and CYP2B6 in catalyzing $\mathrm{N}$-dechloroethylation of cyclophosphamide and ifosfamide. Biochem Pharmacol. 2000; 59: 961972.CrossRef PubMed

[29] Roy P, Yu LJ, Crespi CL, Waxman DJ. Development of a substrate-activity based approach to identify the major human liver P-450 catalysts of cyclophosphamide and ifosfamide activation based on cDNA-expressed activities and liver microsomal P-450 profiles. Drug Metab Dispos. 1999; 27: 655-666. PubMed

[30] Applied Biosystems, I. User Bulletin \#2: ABI Prism 7700 Sequence Detection System. In; 2001.

[31] Manceau S, Giraud C, Declèves X, Batteux F, Chéreau C, Chouzenoux S, Scherrmann JM, Weill $B$, Perrot JY, Tréluyer JM. Expression and induction by dexamethasone of $\mathrm{ABC}$ transporters and nuclear receptors in a human T-lymphocyte cell line. J Chemother. 2012; 24: 48-55.CrossRef PubMed

[32] Liptrott NJ, Pushpakom S, Wyen C, Fätkenheuer $G$, Hoffmann C, Mauss S, Knechten H, Brockmeyer NH, Hopper-Borge E, Siccardi M, Back DJ, Khoo SH, Pirmohamed M, Owen A; German Competence Network for HIV/AIDS. Association of ABCC10 polymorphisms with nevirapine plasma concentrations in the German Competence Network for HIV/AIDS. Pharmacogenet Genomics. 2012; 22: 10-19. CrossRef PubMed

[33] Nambu T, Hamada A, Nakashima R, Yuki M, Kawaguchi T, Mitsuya H, Saito H. Association of SLCO1B3 polymorphism with intracellular accumulation of imatinib in leukocytes in patients with chronic myeloid leukemia. Biol Pharm Bull. 2011; 34: 114-119.CrossRef PubMed

[34] Giraud C, Manceau S, Treluyer JM. ABC transporters in human lymphocytes: expression, activity and role, modulating factors and consequences for antiretroviral therapies. Expert Opin Drug Metab Toxicol. 2010; 6: 571-589.CrossRef PubMed

[35] Takekuma Y, Kakiuchi H, Yamazaki K, Miyauchi S, Kikukawa T, Kamo N, Ganapathy V, Sugawara M. Difference between pharmacokinetics of mycophenolic acid (MPA) in rats and that in humans is caused by different affinities of MRP2 to a glucuronized form. J Pharm Pharm Sci. 2007; 10: 71-85. PubMed

[36] Naesens M, Kuypers DR, Verbeke K, Vanrenterghem $Y$. Multidrug resistance protein 2 genetic polymorphisms influence mycophenolic acid exposure in renal allograft recipients. Transplantation. 2006; 82: 1074-1084.CrossRef PubMed

[37] Miura M, Kagaya H, Satoh S, Inoue K, Saito M, Habuchi T, Suzuki T. Influence of drug transporters and UGT polymorphisms on pharmacokinetics of phenolic glucuronide metabolite of mycophenolic acid in Japanese renal transplant recipients. Ther Drug Monit. 2008; 30: 559-564. CrossRef PubMed 
[38] Patel CG, Ogasawara K, Akhlaghi F. Mycophenolic acid glucuronide is transported by multidrug resistance-associated protein 2 and this transport is not inhibited by cyclosporine, tacrolimus or sirolimus. Xenobiotica. 2013; 43: 229-235. CrossRef PubMed

[39] Salphati L, Benet LZ. Modulation of P-glycoprotein expression by cytochrome $\mathrm{P} 4503 \mathrm{~A}$ inducers in male and female rat livers. Biochem Pharmacol. 1998; 55: 387-395.CrossRef PubMed

[40] Kageyama M, Fukushima K, Togawa T, Fujimoto $K$, Taki M, Nishimura A, Ito Y, Sugioka N, Shibata $N$, Takada K. Relationship between excretion clearance of rhodamine 123 and P-glycoprotein (Pgp) expression induced by representative Pgp inducers. Biol Pharm Bull. 2006; 29: 779-784. CrossRef PubMed

[41] Shipkova M, Strassburg CP, Braun F, Streit F Gröne HJ, Armstrong VW, Tukey RH, Oellerich $M$, Wieland $E$. Glucuronide and glucoside conjugation of mycophenolic acid by human liver, kidney and intestinal microsomes. Br J Pharmacol. 2001; 132: 1027-1034.CrossRef PubMed

[42] Haberkorn V, Heydel JM, Mounie J, Artur Y Goudonnet $H$. Vitamin A modulates the effects of thyroid hormone on UDP-glucuronosyltransferase expression and activity in rat liver. Mol Cell Endocrinol. 2002; 190: 167-175.CrossRef PubMed

[43] Tokura Y, Shikami M, Miwa H, Watarai M, Sugamura $K$, Wakabayashi $M$, Satoh A, Imamura A, Mihara H, Katoh Y, Kita K, Nitta M. Augmented expression of P-gp/multi-drug resistance gene by all-trans retinoic acid in monocytic leukemic cells. Leuk Res. 2002; 26: 29-36. CrossRef PubMed

[44] Buckley DB, Klaassen C. D. Induction of Mouse UDP-Glucuronosyltransferase mRNA Expression in Liver and Intestine by Activators of AhR, CAR, PXR, PPAR \{alpha $\}$, and Nrf2. Drug Metab Dispos. 2009; 37: 847-856.CrossRef PubMed

[45] Chen TL, Passos-Coelho JL, Noe DA, Kennedy $M J$, Black KC, Colvin OM, Grochow LB. Nonlinear pharmacokinetics of cyclophosphamide in patients with metastatic breast cancer receiving high-dose chemotherapy followed by autologous bone marrow transplantation. Cancer Res. 1995; 55: 810-816. PubMed

[46] Lu Y, Bratton S, Heydel JM, Radominska-Pandya $A$. Effect of retinoids on UDP-glucuronosyltransferase 2B7 mRNA expression in Caco-2 cells. Drug Metab Pharmacokinet. 2008; 23: 364-372. CrossRef PubMed

[47] Anderson GD. Gender differences in pharmacological response. Int Rev Neurobiol. 2008; 83: 1-10.CrossRef PubMed

[48] Dooley MA, Hogan S, Jennette C, Falk R; Glomerular Disease Collaborative Network. Cyclophosphamide therapy for lupus nephritis: poor renal survival in black Americans. Kidney Int. 1997; 51: 1188-1195.CrossRef PubMed

[49] Marzolini C, Paus E, Buclin T, Kim RB. Polymorphisms in human MDR1 (P-glycoprotein): recent advances and clinical relevance. Clin Pharmacol Ther. 2004; 75: 13-33. CrossRef PubMed

[50] Zhang J, Tian Q, Yung Chan S, Chuen Li S, Zhou S, Duan W, Zhu YZ. Metabolism and transport of oxazaphosphorines and the clinical implications.
Drug Metab Rev. 2005; 37: 611-703.CrossRef PubMed 